Int. J. Electrochem. Sci., 14 (2019) $7871-7883$

\title{
Electrochemical Performance of the Pd/C Catalyst Synthesized by Polyol Process
}

\author{
Shaofeng $\mathrm{Yu}^{l}$,Qiong $\mathrm{Han}^{1}$,Yingjia Yang ${ }^{1}$, Xuli Ma ${ }^{1}$, Lizhen $\mathrm{Gao}^{1}$, Shaohui Yan ${ }^{1, *}$, Yucheng $W u^{2, *}$, \\ Liquan $\mathrm{Lu}^{3}$ \\ ${ }^{1}$ College of Environmental Science and Engineering, Taiyuan University of Technology, Taiyuan, \\ 030024, China \\ ${ }^{2}$ MOE Key Laboratory for Interface Science and Engineering in Advanced Materials and Research \\ Center of Advanced Materials Science and Technology, Taiyuan University of Technology, Taiyuan, \\ 030024, China \\ ${ }^{3}$ College of Mechatronic Engineering, North University of China, Taiyuan 030051, China \\ *E-mail: yanshaohui@tyut.edu.cn, wyc@tyut.edu.cn
}

doi: $10.20964 / 2019.08 .48$

Received: 2 April 2019/ Accepted: 24 May 2019 / Published: 30 June 2019

Apolyol process is employed to synthesize $\mathrm{Pd}$ nanoparticles supported on carbon $(\mathrm{Pd} / \mathrm{C})$, for developing an electrocatalyst with excellent performance for methanol oxidation. The results show that this method has a high efficiency for the Pd nanoparticles depositing on the carbon support. Moreover, the average diameter of the $\mathrm{Pd}$ nanoparticles decreases with the amount of $\mathrm{KOH}$ solution employed during the catalyst synthesis. The highest electrochemical activity of the $\mathrm{Pd} / \mathrm{C}$ catalyst for the methanol oxidation in $0.1 \mathrm{M} \mathrm{KOH}$ solution with $1.0 \mathrm{M}$ methanol at $25{ }^{\circ} \mathrm{C}$ reaches to $447.4 \mathrm{~mA} \mathrm{mg}^{-1} \mathrm{Pd}^{-}$The activity difference between the $\mathrm{Pd} / \mathrm{C}$ catalysts prepared at $200\left(447.4 \mathrm{~mA} \mathrm{mg}^{-1} \mathrm{Pd}\right)$ and $180{ }^{\circ} \mathrm{C}(435.8$ $\mathrm{mA} \mathrm{mg}{ }^{-1} \mathrm{Pd}$ ) for the methanol electrooxidation is very small, showing that the polyol process is suitable for the preparation of the $\mathrm{Pd} / \mathrm{C}$.

Keywords: Direct methanol fuel cells (DMFCs), Pd nanoparticles, Methanol electrooxidation, Electrocatalysis, Nanomaterials

\section{FULL TEXT}

(C) 2019 The Authors. Published by ESG (www.electrochemsci.org). This article is an open access article distributed under the terms and conditions of the Creative Commons Attribution license (http://creativecommons.org/licenses/by/4.0/). 